\title{
INFUSION OF CONVALESCENT PLASMA IS ASSOCIATED WITH CLINICAL IMPROVEMENT IN CRITICAlly ILl PATIENTS WITH COVID-19: A COMMENT
}

Dear Editor,

I would like to share ideas on the publication by Olivares-Gazca et al. ${ }^{1}$, titled: Infusion of convalescent plasma is associated with clinical improvement in critically ill patients with COVID-19: A pilot study. The authors stated that "although other treatments were also administered to the patients and as a result data are difficult to interpret, it seems that the addition of CoPla improved pulmonary function ${ }^{1}$." In fact, it is possible that convalescent plasma therapy might be useful in management of the COVID-19 patients. However, it requires a good plasma preparation and there is a controversial issue on the possible unwanted effect of this mode of treatment ${ }^{2}$. The persistence of viral particle in some patients recovered from illness is a big issue to be mentioned and there is still no clinical studies to verify whether the contaminated plasma in that case can cause problem to the patient or not ${ }^{2,3}$. Of interest, the present report from Olivares-Gazca et al. can give preliminary data for a short-term safety ${ }^{1}$. Nevertheless, it still requires further follow-up in a larger group to verify long-term effect. During the COVID-19 crisis, we usually seek and use for new treatment, but we should not forget to think about the safety. Regarding plasma therapy, it still requires more collective data to verify the efficacy and safety.

\section{REFERENCES}

1. Olivares-Gazca JC, Priesca-Marín JM, Ojeda-Laguna M, GarcesEisele J, Soto-Olvera S, Palacios-Alonso A, et al. Infusion of convalescent plasma is associated with clinical improvement in critically ill patients with covid-19: a pilot study. Rev Invest Clin. $2020 \cdot 72 \cdot 159-64$

2. Wiwanitkit V. Convalescent plasma therapy in the treatment of COVID-19: some considerations: correspondence. Int J Surg. 2020;80:26.

3. Joob B, Wiwanitkit V. Convalescent plasma and covid-19 treatment. Minerva Med. 2020; [Epub ahead of print].

\section{VIROJ WIWANITKIT*}

Department of Community Medicine, "Dr DY Patil" University, Pune, India

*Corresponding author:

Viroj Wiwanitkit

E-mail:wviroj@yahoo.com
Received for publication: 30-06-2020

Approved for publication: 01-09-2020

DOI: $10.24875 /$ RIC.20000320

0034-8376 / (c) 2020 Revista de Investigación Clínica. Published by Permanyer. This is an open access article under the CC BY-NC-ND license (http://creativecommons.org/licenses/by-nc-nd/4.0/). 


\section{AUTHORS' REPLY}

The letter by Professor Viroj Wiwanitkit is very much appreciated. It refers to our paper in a small subset of patients in whom both efficacy and safety issues were addressed after infusing COVID-19 convalescent plasma to COVID-19 patients ${ }^{1}$; safety concerns are raised by him. Very recently, a study by Mayo Clinic physicians ${ }^{2}$ about the experience in more than

\section{REFERENCES}

1. Olivares-Gazca JC, Priesca-Marín JM, Ojeda-Laguna M, GarcesEisele J, Soto-Olvera S, Palacios-Alonso A, et al. Infusion of convalescent plasma is associated with clinical improvement in
5000 patients that received convalescent plasma as part of the Food and Drug Administration Expanded Access Program informed serious adverse effects in $<1 \%$. Accordingly, safety issues with the use of convalescent plasma therapy seem to be properly settled down. This study, which is currently in press², suggests that convalescent plasma therapy in COVID-19 patients appears to be a safe procedure. Thank you for your interest in our study.

critically ill patients with covid-19: a pilot study. Rev Invest Clin. 2020;72:159-64

2. Willis VC, Arriaga $Y$, Weeraratne $D$, Reyes F, Jackson GP. A narrative review of emerging therapeutics for COVID-19. Mayo Clin Proc Innov Qual Outcomes. 2020; [Epub ahead of print].

\section{Guillermo J. Ruiz-Argüelles*}

Centro de Hematología y Medicina Interna, Clínica Ruiz, Puebla, Pue., Mexico

*Corresponding author:

Guillermo J. Ruiz-Argüelles

E-mail: gruiz1@clinicaruiz.com
Received for publication: 25-08-2020

Approved for publication: 01-09-2020

DOI: 10.24875/RIC.M20000004 